\title{
Perbandingan Tiga Dosis Gabapentin Oral terhadap Nyeri Pascabedah, Sedasi, dan Mual-Muntah pada Histerektomi Total dengan Anestesi Spinal
}

\author{
Rakhmat Ilhamsyah, Syafruddin Gaus, Faisal Muchtar, Abdul Wahab \\ Departemen Anestesiologi \& Terapi Intensif Fakultas Kedokteran Universitas Hasanuddin-RSUP Dr. Wahidin \\ Makassar
}

\begin{abstract}
Abstrak
Latar Belakang: Gabapentin dapat mencegah nyeri nosiseptif, nyeri neuropatik, inflamasi akut dan mengurangi nyeri pasca operasi.

Tujuan: penelitian ini membandingkan tiga dosis gabapentin oral pada operasi histerektomi total dengan anestesi spinal untuk efeknya pada sedasi, mual-muntah, dan nyeri pascabedah

Subjek dan Metode: Desain yang digunakan pada penelitian ini adalah uji klinis acak tersamar tunggal. Sampel terbagi dalam kelompok G600: gabapentin 600 mg, kelompok G750 gabapentin 750 mg dan kelompok G900: gabapentin $900 \mathrm{mg}$ dengan jumlah sampel masing-masing 14 orang. Data dianalisis menggunakan uji statistik uji Mann Whitney U.

Hasil: Perbandingan analgesik tambahan pascabedah kelompok G600 membutuhkan lebih banyak analgesik tambahan dibanding kelompok G750 ( $\mathrm{p}=0,021)$ dan begitu juga untuk kelompok G750 dibanding kelompok G900(p = 0,004). Perbandingan kelompok G600 dan G750 untuk skor sedasi dan agitasi Richmond berbeda bermakna pada jam ke-3,6, dan 9 (nilai p 0,004; 0,007; dan 0,03) dan kelompok G600 dan G900 juga berbeda bermakna pada jam ke-3,6, dan $9(\mathrm{p}=0,007)$. Untuk post operative nausea and vomiting (PONV) terdapat perbedaan bermakna antara kelompok G600 dan G900 dan juga antara kelompok G750 dan G900 (p=0,043).

Simpulan: Pemberian gabapentin oral $900 \mathrm{mg}$ memberikan total rescue analgetik paling sedikit dibanding dengan pemberian gabapentin $600 \mathrm{mg}$ dan $750 \mathrm{mg}$. Ketiga kelompok gabapentin mengalami efek samping sedasi ringan. Kejadian PONV paling rendah pada kelompok gabapentin $900 \mathrm{mg}$.
\end{abstract}

Kata kunci: gabapentin, nyeri, durasi analgesia, sedasi, PONV, histerektomi total, spinal anestesi

\section{Comparison Between Three Doses of Oral Gabapentin Against Postoperative Pain, Sedation, and Nausea-Vomiting in Total Hysterectomy with Spinal Anesthesia}

\begin{abstract}
Background: Gabapentin can prevent nociceptive pain, neuropathic pain, acute inflammation and reduce postoperative pain

Objective: this study aimed to compare three doses of oral gabapentin in total hysterectomy with spinal anesthesia for its effect on sedation, postoperative nausea and vomiting, and post operative pain

Subject and Method: This study was a single blind randomized clinical trial. Samples were divided into groups of G600: gabapentin 600 mg, group G750 gabapentin 750 mg and group G900: gabapentin 900 mg with the number of samples was 14 people each. Data were analyzed using statistical analysis using the Mann Whitney U test.

Results: Comparison of postoperative adjunctive analgesics in the G600 group required more additional analgesics than the G750 group $(p=0.021)$ and likewise for the G750 group compared to the G900 group $(p=0.004)$. Comparison of the G600 and G750 groups for sedation and agitation scores for Richmond was significantly different at the 3.6 and 9 hours (p value 0.004; 0.007; and 0.03) and the G600 and G900 groups were also significantly different at the 3.6 hour, and $9(\mathrm{p}=0.007)$. For post operative nausea and vomiting (PONV), there were significant differences between the G600 and G900 groups and also between the G750 and G900 groups ( $p=0.043$ ).

Conclusion: Gabapentin oral $900 \mathrm{mg}$ with the least total analgesic rescue compared to gabapentin $600 \mathrm{mg}$ and 750 $\mathrm{mg}$. All three gabapentin groups experienced mild side effects of sedation. The lowest incidence of PONV was in the gabapentin $900 \mathrm{mg}$ group
\end{abstract}

Key words: Gabapentin, pain, analgesia duration, sedation, PONV, hysterectomy total, spinal anesthesia 


\section{Pendahuluan}

Konsep terbaru analgesia pascabedah adalah kombinasi beberapa jenis analgetik seperti opioid, obat anti-inflamasi nonsteroid (OAINS), parasetamol, ketamin dosis rendah, dan juga pemberian anestetik lokal perioperatif. Obat-obat tersebut masing-masing memiliki keterbatasan sehingga terus dikembangkan penelitian untuk mendapatkan obat adjuvan yang mempunyai efek analgetik serta dapat meningkatkan kualitas analgesia opioid, mengurangi kebutuhan opioid, mencegah atau mengurangi toleran. Obat analgesia yang baik adalah yang mempunyai efek meningkatkan kualitas analgesia opioid, toleransi baik terhadap opioid, mengurangi ansietas, dan juga tidak ada efek samping yang dimiliki oleh analgesia yang lain, mungkin dapat menjadi adjuvant analgesia perioperatif. ${ }^{1-3}$

Obat dengan karakteristik seperti di atas antara lain adalah golongan gabapentinoid seperti gabapentin dan pregabalin. Kedua obat ini adalah obat yang sering digunakan sebagai antikonvulsan yang kemudian diketahui dapat digunakan untuk penatalaksanaan nyeri akut pascabedah dan nyeri kronik. $^{2}$ Pengobatan nyeri tradisional dengan opioid saja saat ini sudah tidak memadai lagi. Untuk mengoptimalkan perawatan nyeri dan hasil pascabedah, analgesik baru dan kombinasi baru analgesik yang sudah ada terus dicari. ${ }^{4,5}$ Gabapentin adalah obat dengan struktur kimia yang meniru neurotransmitter gamma amino butyric acid (GABA) dan bekerja pada reseptor otak yang sama. Namun, modus tindakannya tidak sepenuhnya dipahami. Di antara mekanisme lain seperti penurunan sintesis neurotransmitter glutamat, gabapentin bekerja dengan mengikat subunit $\alpha 2 \delta$ saluran $\mathrm{Ca} 2+$ yang bergantung pada tegangan. Obat ini telah diperkenalkan sebagai obat antiepilepsi, tetapi terbukti efektif dalam mengendalikan nyeri neuropatik. ${ }^{4,6}$

Baru-baru ini, gabapentin telah digunakan untuk mengurangi kecemasan pra-operasi, nyeri akut pascabedah, kebutuhan opioid pascabedah, mualmuntah pascabedah, dan delirium. Kemanjuran dan keamanan gabapentin oral pra operasi pada nyeri dan konsumsi opioid diteliti pada pasien yang menjalani berbagai prosedur bedah sebagai total histerektomi abdominal, histerektomi vaginal, torakotomi, dan operasi tulang belakang tetapi kesimpulan tentang dosis optimal dan durasi pengobatan tidak dapat dibuat karena heterogenitas uji coba. ${ }^{4,7,8}$ Penelitian lainnya menilai efektivitas gabapentin $600 \mathrm{mg}$ dan $900 \mathrm{mg}$ per oral kombinasi ketorolak $30 \mathrm{mg} / 8$ jam intravena sebagai analgesia pascabedah pada histerektomi total dengan anestesi umum didapatkan gabapentin $600 \mathrm{mg}$ dengan gabapentin $900 \mathrm{mg}$ kombinasi ketorolak 30 $\mathrm{mg} / 8$ jam sebagai analgesia pascabedah tidak berbeda efektivitasnya dalam mengurangi nilai visual analog scale (VAS) dan kebutuhan rescue analgesia petidin selama 24 jam pascabedah. ${ }^{1}$ Karena gabapentin tampaknya mencegah nyeri nosiseptif dan inflamasi akut dan mungkin mengurangi nyeri pasca operasi, oleh karena itu penelitian ini bertujuan untuk membandingkan gabapentin oral $600 \mathrm{mg}, 750 \mathrm{mg}$ dan $900 \mathrm{mg}$ pada operasi histerektomi total dengan anestesi spinal efeknya pada sedasi, mual-muntah, dan nyeri pascabedah.

\section{Subjek dan Metode}

Penelitian ini menggunakan uji klinis acak tersamar tunggal dengan tujuan untuk membandingkan tiga dosis gabapentin oral pada operasi histerektomi total dengan anestesi spinal untukefeknya padasedasi, mual-muntah, dan nyeri pascabedah. Kriteria inklusi: umur 30-60 tahun, berat badan: $50-70 \mathrm{~kg}$, tinggi badan: $150-170$ $\mathrm{cm}$, indeks massa tubuh (IMT): 18,5-29,9 kg/m2 dan American Society of Anesthesiologist (ASA) PS I-II. Kriteria eksklusi: adanya kontraindikasi dilakukan subarachnoid block (SAB), penderita dengan riwayat penyakit asma, penderita dengan riwayat hipertensi, penyakit jantung dan kardiovaskuler, riwayat diabetes mellitus (DM), adanya riwayat alergi terhadap bahan penelitian, penderita dengan riwayat epilepsi atau sedang menggunakan obat antiepilepsi, penderita dengan gangguan fungsi ginjal atau hati, penderita dengan pengguna alkohol, kehamilan dengan komplikasi obstetrik seperti hipertensi, oligohidramnion, polihidramnion, pendarahan antepartum, penderita dengan gangguan 
kejiwaan. Kriteria drop out: terjadi komplikasi anestesi atau pembedahan, konversi ke anestesi umum selama operasi, pasien mengundurkan diri dari penelitian.

Penelitian ini dilakukan di RSUP Dr. Wahidin Sudirohusodo Makassar dan jejaringnya dan dimulai pada bulan Mei sampai September 2020. Penelitian ini dibagi menjadi tiga kelompok yaitu kelompok G600: kelompok gabapentin 600 mg menerima dua kapsul gabapentin $300 \mathrm{mg}$. Kelompok G750: kelompok gabapentin $750 \mathrm{mg}$ menerima dua kapsul gabapentin $300 \mathrm{mg}$ dan 1 kapsul gabapentin $150 \mathrm{mg}$. Kelompok G900: kelompok gabapentin $900 \mathrm{mg}$ menerima tiga kapsul gabapentin $300 \mathrm{mg}$ pada histerektomi total dengan anestesi spinal. Jumlah sampel total 42 pasien, masing-masing kelompok 14 pasien.

Pasien yang memenuhi kriteria inklusi dialokasikan ke dalam kelompok G 600, G 750, dan G 900. Obat penelitian diberikan melalui mulut dengan seteguk air satu jam sebelum waktu yang diharapkan dari sayatan bedah. Obat ini diberikan oleh ahli anestesi, yang juga melakukan penilaian selanjutnya. Tidak ada premedikasi lain yang diberikan saat ini. Evaluasi pra operasi untuk semua kelompok termasuk pemeriksaan fisik dan laboratorium (kadar hemoglobin, jumlah trombosit, glukosa darah acak, kreatinin serum, tes fungsi hati, waktu protrombin (PT) dan rasio normalisasi internasional (INR)). Sebelum dilakukan anestesi spinal dilakukan loading cairan koloid dengan HES 6\% 250 cc. Anestesi spinal dilakukan dengan posisi dekubitus lateral kiri pada celah sendi vertebra L3-L4. Kedua kelompok dilakukan anestesi spinal dengan jarum spinal Spinocan ${ }^{\circledR} 25 \mathrm{G}$, bupivakain hiperbarik $0,5 \%$ (Regivell $^{\circledR}$ ) $8 \mathrm{mg}$ dengan ajuvan fentanyl $25 \mu \mathrm{g}$ dengan kecepatan penyuntikan 3 detik/cc. Pasien dalam posisi left lateral decubitus (LLD) dan head down $10^{\circ}$.

Setelah blok sensorik tercapai pasien diposisikan netral. Dilakukan pemeriksaan ketinggian blok otonom dengan cold test, blok sensorik dengan pin prick test, dan blok motorik dengan skor Bromage. Pembedahan dimulai jika blok sensorik setinggi Th-6. Bila tekanan arteri rerata (TAR)
$<25 \%$ dari nilai basal, diberikan efedrin $5-10$ $\mathrm{mg}$ intravena. Pain management pascabedah diberikan ketorolak $30 \mathrm{mg} / 8$ jam/intravena. Setelah operasi selesai pasien dipindahkan ke unit perawatan anestesi post anesthesia care unit (PACU) dilakukan pengamatan hal-hal berikut: Waktu pemberian rescue analgetik pasca operasi, jumlah dosis dicatat serta durasi analgesia (didefinisikan sebagai waktu sejak dimulainya anestesi spinal hingga diberikan analgetik rescue), yang dinilai oleh numerical rating scale (NRS) sistem penilaian yang digunakan oleh pasien, pasien memberi tanda pada garis horizontal yang bertuliskan "tidak ada rasa sakit sama sekali" di satu ujung pada 0 , dan "rasa sakit terburuk yang bisa dibayangkan" di ujung lainnya di 10 dan direkam awalnya setiap jam selama 10 jam pertama dan kemudian setelah setiap 4 jam hingga 24 jam. Jika NRS $\mathrm{P} 4$, fentanyl $0,5-1 \mathrm{mcg} / \mathrm{kgBB}$ diberikan sebagai rescue analgesia (diulangi jika diperlukan selama 24 jam pertama pasca operasi), jumlah dosis dan total kebutuhan analgesik dicatat. Insiden mual dan muntah pasca operasi post operative nausea and vomiting (PONV): untuk setiap pasien dinilai dengan kejadian mual dan muntah pascabedah yang dialami pasien. Tingkat sedasi dinilai pada interval 3 jam untuk 12 jam pertama dan kemudian setiap 6 jam untuk 12 jam berikutnya pasca operasi dengan menggunakan skor sedasi dan agitasi Richmond.

Sebelum penelitian dilaksanakan, peneliti meminta keterangan kelayakan etik (ethical clearance) dari komisi Etik Penelitian Biomedis pada manusia Fakultas Kedokteran Universitas Hasanuddin. Semua keluarga penderita yang memenuhi kriteria inklusi diberi penjelasan secara lisan dan menandatangani lembar persetujuan untuk ikut dalam penelitian secara sukarela. Bila karena suatu alasan penderita/keluarga penderita berhak mengundurkan diri dari penelitian ini. Data yang diperoleh diolah dan hasilnya ditampilkan dalam bentuk narasi, tabel atau grafik berupa ratarata, dan standar deviasi, maupun frekuensi dan persentase, dengan menggunakan SPSS 25 untuk Macintosh. Data ditunjukkan dengan rata-rata maupun frekuensi dari umur, berat badan, tinggi badan, index massa tubuh (IMT), skor sedasi, 
NRS, kejadian mual dan muntah pada masingmasing kelompok. Berdasarkan jenis dan bentuk data yang didapatkan kemudian ditentukan metode uji statistik yang sesuai. Data kategorik disajikan sebagai frekuensi (n) dan persentase. Variabel tersebut diuji dengan chi-square test. Variabel numerik disajikan dalam bentuk median (jangkauan interkuartil) dan variabel diuji dengan uji independent T dan uji Mann-Whitney $\mathrm{U}$.

\section{Hasil}

Penelitian ini dilakukan selama lima bulan, yaitu bulan Mei sampai dengan September 2020 dan diperoleh 42 pasien yang bersedia mengikuti penelitian dan memenuhi kriteria inklusi dibagi menjadi tiga kelompok, yaitu kelompok yang mendapat gabapentin $600 \mathrm{mg}, 750 \mathrm{mg}$ dan 900 mg sebelum dilakukan pembedahan dengan anestesi spinal.

Perbandingan Numerical Rating Scale (NRS)

Dari hasil analisis pada tabel 1 menunjukkan perbandingan NRS diam kelompok G600 dan G750 pada jam ke- 1,2,3,4,5,7,8,9,10,14,18,22,24 didapatkan perbedaan yang tidak bermakna $(\mathrm{p}>0,05)$ dan NRS diam jam ke-6 didapatkan perbedaan bermakna $(p=0,04)$ dengan NRS diam tertinggi pada kelompok $600 \mathrm{mg}$. Pada tabel 1 menunjukkan perbandingan NRS diam G600 dan G900 dimana pada jam ke 1,2,3,4,5,9,10,14,18,22, dan 24 didapatkan perbedaan yang tidak bermakna $(\mathrm{p}>0,05)$ dan pada jam ke-6,7, dan 8 didapatkan perbedaan bermakna $(\mathrm{p}<0,05)$.

\section{Analgesik Tambahan Pascabedah}

Hasil analisis analgesik tambahan pascabedah pada kelompok $600 \mathrm{mg}, 750 \mathrm{mg}$ dan $900 \mathrm{mg}$ dapat kita lihat pada tabel 2. Pada tabel 2 menunjukkan perbandingan analgesik tambahan pascabedah pada kelompok G600 dan G750 dimana lebih banyak diberikan fentanyl pada kelompok G600 dengan total $820 \mathrm{mcg}$ pemberian rescue sebanyak 2 kali didapatkan pada 9 sampel sedangkan untuk kelompok G750 didapatkan total dosis fentanyl 170 mcg dengan pemberian rescue 1 kali pada 2 sampel dan rescue 2 kali pada 1 sampel. Didapatkan perbedaan bermakna dengan nilai $\mathrm{p}$ $=0,021$.

Tabel 1. Perbandingan NRS Diam Dosis $600 \mathrm{mg}, 750 \mathrm{mg}$ dan $900 \mathrm{mg}$

\begin{tabular}{|c|c|c|c|c|c|c|}
\hline \multirow[t]{2}{*}{ NRS } & \multicolumn{3}{|c|}{ Dosis gabapentin (mg) } & \multicolumn{3}{|c|}{$\mathrm{P}$} \\
\hline & $\begin{array}{l}\text { G600 } \\
(n=14\end{array}$ & $\begin{array}{l}\text { G750 } \\
(n=14)\end{array}$ & $\begin{array}{l}\text { G900 } \\
(n=14)\end{array}$ & $\begin{array}{l}\text { G600- } \\
\text { G750 }\end{array}$ & G600-G900 & $\begin{array}{l}\text { G750- } \\
\text { G900 }\end{array}$ \\
\hline NRS 1 jam & $0(0-2)$ & $0(0-1,25)$ & $0,5(0-2)$ & $0,31^{\mathrm{ns}}$ & $0,96^{\mathrm{ns}}$ & $0,23^{\mathrm{ns}}$ \\
\hline NRS 2 jam & $0(0-2)$ & $0(0-1,25)$ & $0,5(0-2)$ & $0,28^{\mathrm{ns}}$ & $0,92^{\text {ns }}$ & $0,23^{\text {ns }}$ \\
\hline NRS 3 jam & $0,5(0-3)$ & $0,5(0-2)$ & $1(0-2)$ & $0,57^{\mathrm{ns}}$ & $0,90^{\text {ns }}$ & $0,62^{\mathrm{ns}}$ \\
\hline NRS 4 jam & $1(0-2)$ & $1(0-2)$ & $1(0-1)$ & $0,46^{\mathrm{ns}}$ & $0,21^{\mathrm{ns}}$ & $0,68^{\mathrm{ns}}$ \\
\hline NRS 5 jam & $1,5(0-2,25)$ & $1(0-2)$ & $1(0-1)$ & $0,72^{\mathrm{ns}}$ & $0,29 \mathrm{~ns}$ & $0,44^{\mathrm{ns}}$ \\
\hline NRS 6 jam & $2(1,5-2,25)$ & $1(0-2)$ & $1(0-1,25)$ & $0,04 *$ & $0,01 *$ & $0,77 \mathrm{~ns}$ \\
\hline NRS 7 jam & $2(0,75-2,25)$ & $1(0-2)$ & $1(0-1)$ & $0,11^{\mathrm{ns}}$ & $0,03 *$ & $0,62^{\mathrm{ns}}$ \\
\hline NRS 8 jam & $2(1-2)$ & $1(0-2)$ & $1(0-1)$ & $0,09^{\text {ns }}$ & $0,03 *$ & $0,66^{\mathrm{ns}}$ \\
\hline NRS 9 jam & $1(0-2)$ & $1(0-2)$ & $1(0-1)$ & $0,88^{\mathrm{ns}}$ & $0,49^{\text {ns }}$ & $0,69^{\text {ns }}$ \\
\hline NRS 10 jam & $1(0-2,25)$ & $0,5(0-2)$ & $1(0-1)$ & $0,89^{\text {ns }}$ & $0,39^{\text {ns }}$ & $0,48^{\mathrm{ns}}$ \\
\hline NRS 14 jam & $0(0-2)$ & $0,5(0-2)$ & $1(0-1,25)$ & $0,69^{\text {ns }}$ & $0,94^{\text {ns }}$ & $0,79^{\text {ns }}$ \\
\hline NRS 18 jam & $0,5(0-2)$ & $1(0-2)$ & $1(0-1,25)$ & $0,61^{\mathrm{ns}}$ & $1^{\mathrm{ns}}$ & $0,59^{\text {ns }}$ \\
\hline NRS 22 jam & $0,5(0-1,25)$ & $1(0-2)$ & $1(0-1,25)$ & $0,62^{\text {ns }}$ & $0,84^{\mathrm{ns}}$ & $0,69^{\text {ns }}$ \\
\hline NRS 24 jam & $0(0-1)$ & $0,5(0-2)$ & $1(0-1)$ & $0,53^{\mathrm{ns}}$ & $0,58^{\mathrm{ns}}$ & $0,77^{\mathrm{ns}}$ \\
\hline
\end{tabular}

Data ditampilkan dalam median (jangkauan interkuartil 25-75). Data diuji dengan Uji Mann-Whitney U; ns: not significant. 
Tabel 2. Perbandingan Analgesik Tambahan Pascabedah Dosis $600 \mathrm{mg}, 750 \mathrm{mg}$, dan $900 \mathrm{mg}$

\begin{tabular}{|c|c|c|c|c|c|c|}
\hline \multirow{2}{*}{$\begin{array}{c}\text { Analgesik } \\
\text { tambahan } \\
\text { pascabedah } \\
\text { (Fentanyl } 1 \\
\text { mcg/kgBB }\end{array}$} & \multicolumn{4}{|c|}{ Dosis gabapentin (mg) } & \multicolumn{2}{|c|}{$\mathrm{P}$} \\
\hline & $\begin{array}{c}\text { G600 } \\
(n=14)\end{array}$ & $\begin{array}{c}\text { G750 } \\
(n=14)\end{array}$ & $\begin{array}{l}\text { G900 } \\
(n=14)\end{array}$ & $\begin{array}{l}\text { G600/ } \\
\text { G750 }\end{array}$ & G600/G900 & $\begin{array}{l}\text { G750- } \\
\text { G900 }\end{array}$ \\
\hline Satu dosis & - & $2(12,5 \%)$ & $\begin{array}{c}1 \\
(6,25 \%)\end{array}$ & & & \\
\hline Dua dosis & $9(56,25 \%)$ & $1(6,25 \%)$ & - & & & \\
\hline & & & & $0,021 *$ & $0,004 *$ & $0,004 *$ \\
\hline $\begin{array}{l}\text { Total dosis } \\
\text { (mcg) }\end{array}$ & 820 & 170 & 30 & & & \\
\hline
\end{tabular}

Tabel 3. Perbandingan Skor Sedasi dan Agitasi Richmond Dosis 600 mg, 750 mg dan 900 mg

\begin{tabular}{|c|c|c|c|c|c|c|}
\hline \multirow[t]{2}{*}{ NRS } & \multicolumn{3}{|c|}{ Dosis gabapentin (mg) } & \multicolumn{3}{|c|}{$\mathrm{P}$} \\
\hline & $\begin{array}{l}\text { G600 } \\
(n=14\end{array}$ & $\begin{array}{l}\text { G750 } \\
(n=14)\end{array}$ & $\begin{array}{l}\text { G900 } \\
(n=14)\end{array}$ & G600-G750 & G600-G900 & $\begin{array}{l}\text { G750- } \\
\text { G900 }\end{array}$ \\
\hline sedasi 1 jam & $0(0-0)$ & $0(0-0)$ & $0(0-0)$ & $0.94^{\mathrm{ns}}$ & $0,35^{\mathrm{ns}}$ & $0,44^{\mathrm{ns}}$ \\
\hline sedasi 3 jam & $0(0-1)$ & $0(0-0)$ & $0(0-0)$ & $0.004^{*}$ & $0,007^{*}$ & $0,15^{\mathrm{ns}}$ \\
\hline sedasi 6 jam & $0(0-1)$ & $0(0-0)$ & $0(0-0)$ & $0.007^{*}$ & $0.007^{*}$ & $1^{\mathrm{ns}}$ \\
\hline sedasi 9 jam & $0(0-1)$ & $0(0-0)$ & $0(0-0)$ & $0.03^{*}$ & $0,007^{*}$ & $0,32^{\mathrm{ns}}$ \\
\hline sedasi 12 jam & $0(0-0)$ & $0(0-0)$ & $0(0-0)$ & $0.55^{\mathrm{ns}}$ & $0,32^{\text {ns }}$ & $0,15^{\mathrm{ns}}$ \\
\hline sedasi 18 jam & $0(0-0)$ & $0(0-0)$ & $0(0-0)$ & $1^{\mathrm{ns}}$ & $1^{\text {ns }}$ & $1^{\text {ns }}$ \\
\hline sedasi 24 jam & $0(0-0)$ & $0(0-0)$ & $0(0-0)$ & $1^{\text {ns }}$ & $1^{\mathrm{ns}}$ & $1^{\text {ns }}$ \\
\hline
\end{tabular}

Data ditampilkan dalam median (jangkauan interkuartil 25-75). Data diuji dengan Uji Mann-Whitney U; ns: $n o t$ significant.

Hasil analisis tabel 5 untuk perbandingan G600 dan G900 dimana kelompok G900 didapatkan total dosis fentanyl $30 \mathrm{mcg}$ yaitu rescue $1 \mathrm{kali}$ pada 1 sampel dan diperoleh perbedaan bermakna dengan nilai $p=0,004$. Juga didapatkan perbedaan bermakna pada analisis perbandingan analgesia tambahan pascabedah kelompok G750 dan G900 dimana nilai $\mathrm{p}=0,004$.
Perbandingan skor sedasi dan agitasi Richmond Dari hasil analisis tabel 3 menunjukkan perbandingan kelompok G600 dan G750 untuk skor sedasi dan agitasi Richmond dimana didapatkan perbedaan bermakna pada jam ke3,6, dan 9 dengan nilai $p$ masing-masing 0,004 ; 0,007; dan 0,03; dan didapatkan perbedaan tidak bermakna pada sedasi jam 1,12,18,24 ( $\mathrm{p}>0,05)$. Dari hasil analisis tabel 3 juga didapatkan

Tabel 4. Perbandingan PONV Dosis $600 \mathrm{mg}, 750 \mathrm{mg}$, dan $900 \mathrm{mg}$

\begin{tabular}{lllllll}
\hline PONV & \multicolumn{2}{l}{ Dosis gabapentin $(\mathrm{mg})$} & \multicolumn{2}{c}{$\mathrm{p}$} \\
& $\mathrm{G} 600$ & $\mathrm{G} 750$ & $\mathrm{G} 900$ & $\mathrm{G} 600-$ & G600- & G750- \\
& $(\mathrm{n}=14)$ & $(\mathrm{n}=14)$ & $(\mathrm{n}=14)$ & $\mathrm{G} 750$ & $\mathrm{G} 900$ & G900 \\
\hline Ya & $7(50 \%)$ & $7(50 \%)$ & $2(12,5 \%)$ & $1^{\text {ns }}$ & $\mathbf{0 , 0 4 3}^{*}$ & $\mathbf{0 , 0 4 3}^{*}$ \\
Tidak & $7(50 \%)$ & $7(50 \%)$ & $12(85,71)$ & & & \\
\hline
\end{tabular}

Data ditampilkan dalam jumlah (\%), Data diuji dengan Uji Chi Square; ns: not significant 
perbedaan bermakna untuk skor sedasi dan agitasi Richmond kelompok G600 dan G900 pada jam ke-3,6, dan 9 masing-masing dengan nilai $\mathrm{p}=$ 0,007 , dan didapatkan perbedaan tidak bermakna pada jam 1,12,18,24 ( $p>0,05)$. Dari hasil analisis pada tabel 3 menunjukkan tidak terdapat perbedaan skor sedasi dan agitasi Richmond yang secara statistik bermakna $(p>0,05)$ antara kelompok G750 dan G900.

\section{Perbandingan PONV}

Dari hasil analisis pada tabel 4 menunjukkan tidak terdapat perbedaan bermakna untuk perbandingan kejadian PONV antara kelompok G600 dan G750 ( $p>0,05)$. Pada analisis tabel 8 didapatkan perbedaan bermakna PONV antara kelompok G600 dan G900 dengan nilai $p=0,043$. Pada tabel 8 juga didapatkan perbedaan bermakna antara kelompok G750 dan G900 dengan nilai $\mathrm{p}=0,043$. Kejadian PONV paling tinggi pada kelompok $600 \mathrm{mg}$ dan $750 \mathrm{mg}$ dengan 7 sampel masingmasing sedangkan terendah pada kelompok 900 mg dengan 2 sampel. Perbandingan PONV diuji menggunakan uji Chi square, dimana $\mathrm{p}<0,05$ dinyatakan bermakna.

\section{Pembahasan}

Karakteristik sampel penelitian kedua kelompok meliputi umur, berat badan, tinggi badan dan IMT. Hasil penelitian menunjukkan bahwa tidak ditemukan perbedaan umur, berat badan, tinggi badan dan IMT yang bermakna antara ketiga kelompok $(p \geq 0,05)$. Untuk variabelvariabel karakteristik pasien tersebut, tidak ditemukan perbedaan yang bermakna secara statistik antara ketiga kelompok. Hal ini menunjukkan adanya homogenitas ketiga kelompok sehingga layak untuk dibandingkan. Dari hasil analisis pada tabel 1 menunjukkan perbandingan NRS diam kelompok G600 dan G750 pada jam ke- 1,2,3,4,5,7,8,9,10,14,18,22,24 didapatkan perbedaan yang tidak bermakna $(\mathrm{p}>0,05)$ dan NRS diam jam ke-6 didapatkan perbedaan bermakna $(p=0,04)$ dengan NRS diam tertinggi pada kelompok $600 \mathrm{mg}$. Perbandingan NRS diam G600 dan G900 dimana pada jam ke $1,2,3,4,5,9,10,14,18,22$, dan 24 didapatkan perbedaan yang tidak bermakna $(\mathrm{p}>0,05)$ dan pada jam ke-6,7, dan 8 didapatkan perbedaan bermakna $(\mathrm{p}<0,05)$. Perbandingan NRS diam kelompok G750 dan G900 pada 24 jam pengamatan didapatkan perbedaan yang tidak bermakna $(p>0,05)$. Walaupun tidak banyak didapatkan uji statistik bermakna, namun saat pengukuran NRS diam paling tinggi ratarata didapatkan pada kelompok G600 dan terendah rata-rata didapatkan pada kelompok G900. Penelitian lainnya tahun 2017 dengan membandingkan efek gabapentin oral $900 \mathrm{mg}$ dengan $600 \mathrm{mg}$ pada pasien yang menjalani seksio sesarea dengan anestesi spinal didapatkan bahwa gabapentin oral $900 \mathrm{mg}$ lebih efektif daripada 600 mg dalam mengurangi nyeri pascabedah sesarea. ${ }^{4}$ Pada penelitian tahun 2016 menilai efektivitas gabapentin $600 \mathrm{mg}$ dan $900 \mathrm{mg}$ per oral kombinasi ketorolak $30 \mathrm{mg} / 8 \mathrm{jam}$ intravena sebagai analgesia pascabedah pada histerektomi total dengan anestesi umum didapatkan gabapentin $600 \mathrm{mg}$ dengan gabapentin 900 mg kombinasi ketorolak $30 \mathrm{mg} / 8$ jam sebagai analgesia pascabedah tidak berbeda efektivitasnya dalam mengurangi nilai VAS selama 24 jam pascabedah. ${ }^{1}$

Penelitian farmakokinetik pada gabapentin menunjukkan bahwa absorbsi gabapentin sangat bergantung dosis obat. Semakin besar dosis yang diberikan maka absorbsi gabapentin akan semakin besar, namun sifat ini hanya terjadi pada pemberian gabapentin sampai dosis $600 \mathrm{mg}$. Pemberian gabapentin lebih dari $600 \mathrm{mg}$ menunjukkan terjadi penurunan absorbsi. Bioavailabilitas gabapentin berbanding terbalik dengan dosis yang diberikan. Semakin besar dosis obat maka bioavailabilitas semakin kecil. Hasil penelitian farmakokinetik tersebut memberikan indikasi bahwa pemberian gabapentin lebih besar dari dosis $600 \mathrm{mg}$ tidak menunjukkan hubungan antara besar dosis yang diberikan dan respons obat yang terjadi. Namun, bila dibandingkan dosis gabapentin $600 \mathrm{mg}$ dengan $1200 \mathrm{mg}$, dapat dipastikan absorbsi dan juga bioavailabilitas gabapentin $1200 \mathrm{mg}$ tetap lebih besar dibandingkan dengan gabapentin 600 mg.

Hasil penelitian tersebut membuktikan bahwa dosis lebih besar dapat menurunkan nilai VAS dengan perbedaan yang bermakna secara statistik, 
namun secara klinis kedua dosis tersebut tidak memberikan efek yang terlalu berbeda sehingga kebutuhan analgetik juga tidak jauh berbeda. ${ }^{5,9,10}$ Pada tabel 2 menunjukkan perbandingan analgesik tambahan pascabedah pada kelompok G600 dan G750 dimana lebih banyak diberikan fentanyl pada kelompok G600 dengan total 820 mcg pemberian rescue sebanyak 2 kali didapatkan pada 9 sampel sedangkan untuk kelompok G750 didapatkan total dosis fentanyl 170 mcg dengan pemberian rescue 1 kali pada 2 sampel dan rescue 2 kali pada 1 sampel. Didapatkan perbedaan bermakna dengan nilai $p=0,021$. Hasil analisis tabel 2 untuk perbandingan G600 dan G900 dimana kelompok G900 didapatkan total dosis fentanyl $30 \mathrm{mcg}$ yaitu rescue 1 kali pada 1 sampel dan diperoleh perbedaan bermakna dengan nilai $p=0,004$. Juga didapatkan perbedaan bermakna pada analisis perbandingan analgesia tambahan pascabedah kelompok G750 dan G900 dimana nilai $p=$ 0,004 . Hal ini menunjukkan bahwa gabapentin $900 \mathrm{mg}$ memiliki waktu paruh lebih panjang dan efek analgesia lebih baik dari dosis $600 \mathrm{mg}$ dan $750 \mathrm{mg}$ dimana dapat mempertahankan VAS $<4$ lebih lama dan rescue analgetik pada grup G900 paling sedikit. Sesuai dengan penelitian lainnya, 175 pasien yang menjalani operasi laminektomi lumbal didapatkan bahwa pasien yang menerima gabapentin $900 \mathrm{mg}$ dan $1200 \mathrm{mg}$ (baik pra- atau pascabedah) menunjukan skor nyeri yang lebih rendah selama 24 jam pertama pascabedah dibanding pasien yang menerima placebo atau gabapentin $600 \mathrm{mg} .{ }^{11,12}$ Waktu pemberian rescue analgetik berhubungan dengan efektivitas preemtif analgesia dan waktu paruh gabapentin serta ketorolak dalam memperpanjang jarak waktu pemberian obat rescue analgetik sehingga efek analgesia akan menurun bila melewati masa kerja obat dalam upaya mempertahankan nilai VAS $<4 .{ }^{1}$

Pada penelitian ini gabapentin dosis 900 mg memberikan analgesia yang lebih baik karena grup ini paling sedikit mendapatkan rescue analgetik dibanding grup lain yang menunjukkan waktu paruh yang lebih panjang dalam mempertahankan VAS $<4$. Penelitian lainnya menilai efek gabapentin $600 \mathrm{mg}$ dan $1200 \mathrm{mg}$ per oral preoperatif terhadap nilai VAS dan pengurangan kebutuhan petidin pascabedah didapatkan gabapentin $1.200 \mathrm{mg}$ per oral preoperatif lebih baik bila dibandingkan dengan $600 \mathrm{mg}$ dalam mengurangi nilai VAS pascabedah pada operasi modifikasi mastektomi radikal, namun tidak mengurangi kebutuhan petidin. ${ }^{13}$

Pada penelitian tahun 2016 menilai efektivitas gabapentin $600 \mathrm{mg}$ dan $900 \mathrm{mg}$ per oral kombinasi ketorolak $30 \mathrm{mg} / 8$ jam intravena sebagai analgesia pascabedah pada histerektomi total dengan anestesi umum didapatkan gabapentin $600 \mathrm{mg}$ dengan gabapentin $900 \mathrm{mg}$ kombinasi ketorolak $30 \mathrm{mg} / 8$ jam sebagai analgesia pascabedah tidak berbeda efektivitasnya pada kebutuhan rescue analgesia petidin selama 24 jam pascabedah. Konsumsi opioid pascabedah berkurang saat menggunakan gabapentin dalam 24 jam pertama setelah operasi (perbedaan rata-rata standar $-1,35$, interval kepercayaan 95\% [CI]: -1,96 hingga $-0,73 ; \mathrm{P}<0,001)$. Terdapat penurunan yang signifikan dalam konsumsi morfin, fentanil, dan tramadol $(\mathrm{P}<0,05) .{ }^{1}$ Pemberian gabapentin bila dikombinasikan dengan analgetik yang samasama mempunyai efek antinosiseptif diharapkan menghasilkan efek sinergis. Penelitian yang telah dilakukan sebelum ini membuktikan bahwa gabapentin mempunyai efek yang sinergistik dengan aksi opioid. Kombinasi gabapentin dan opioid akan meningkatkan efek analgetik opioid, sehingga dapat memberikan efek analgetik yang lebih baik apabila dibandingkan dengan pemberian opioid tunggal. Keuntungan lain yang didapat dari kombinasi gabapentin dan opioid selain kontrol nyeri yang lebih baik adalah terjadi pengurangan opioid yang dibutuhkan sehingga efek samping yang terjadi akibat penggunaan opioid menjadi lebih kecil. ${ }^{5}$ Bila diberikan 2-3 jam sebelum operasi, gabapentin akan mencapai konsentrasi puncak dalam plasma dan otak. Banyak penelitian telah membuktikan bahwa gabapentin yang diberikan dengan dosis 300$1000 \mathrm{mg}$ akan mengurangi konsumsi opioid 20-60\%. Begitu pula dengan waktu pertama untuk pemberian rescue analgesia akan lebih panjang. ${ }^{14,15}$

Untuk mengetahui perbandingan skor sedasi dan agitasi Richmond hasilnya dapat dilihat pada tabel 3. Dari hasil analisis tabel 3 menunjukkan 
perbandingan kelompok G600 dan G750 untuk skor sedasi dan agitasi Richmond dimana didapatkan perbedaan bermakna pada jam ke3,6 , dan 9 dengan nilai $p$ masing-masing 0,004 ; 0,007 ; dan 0,03; dan didapatkan perbedaan tidak bermakna pada sedasi jam 1,12,18,24 ( $p>0,05)$. Dari hasil analisis tabel 3 juga didapatkan perbedaan bermakna untuk skor sedasi dan agitasi Richmond kelompok G600 dan G900 pada jam ke-3,6, dan 9 masing-masing dengan nilai $p=$ 0,007 , dan didapatkan perbedaan tidak bermakna pada jam 1,12,18,24 ( $\mathrm{p}>0,05)$. Tidak terdapat perbedaan skor sedasi dan agitasi Richmond yang secara statistik bermakna $(p>0,05)$ antara kelompok G750 dan G900.

Penelitian lainnya membandingkan efek gabapentin oral $900 \mathrm{mg}$ dengan $600 \mathrm{mg}$ pada pasien yang menjalani seksio sesarea dengan anestesi spinal ada peningkatan yang signifikan secara statistik dalam skor sedasi pasien dalam kelompok $900 \mathrm{mg}$ dibandingkan dengan kelompok $600 \mathrm{mg}$ terutama pada 6 jam, 9 jam, dan 12 jam dengan nilai $p$ (masing-masing 0,008 ; 0,045; dan 0,049), namun tidak ada perbedaan yang signifikan secara statistik. ${ }^{4}$ Penelitian lainnya tahun 2016 melihat efek pemberian gabapentin oral preoperatif pada pascabedah didapatkan dosis gabapentin $300 \mathrm{mg}, 600 \mathrm{mg}$ dan $900 \mathrm{mg}$ tidak menghasilkan sedasi yang signifikan secara statistik namun dosis gabapentin sebelum operasi $1200 \mathrm{mg}$ menghasilkan sedasi pasca operasi yang signifikan dibandingkan dengan kontrol. ${ }^{15}$ Efek samping paling sering dilaporkan dengan penggunaan gabapentin adalah sedasi. Pemberian gabapentinoid dosis besar harus diberikan perhatian khusus, terutama pada pasien rawat jalan. ${ }^{15}$

Pada saat pengamatan, skor sedasi yang didapatkan pada ketiga sampel termasuk skor sedasi ringan dimana selama pengamatan efek samping ini tidak membutuhkan intervensi. Dari hasil analisis pada tabel 4 menunjukkan tidak terdapat perbedaan bermakna untuk perbandingan kejadian PONV antara kelompok G600 dan G750 $(\mathrm{p}=1)$. Pada analisis tabel 4 didapatkan perbedaan bermakna PONV antara kelompok G600 dan G900 dengan nilai $p=0,043$. Pada tabel 8 juga didapatkan perbedaan bermakna antara kelompok G750 dan G900 dengan nilai $p=0,043$. Kejadian PONV paling tinggi pada kelompok $600 \mathrm{mg}$ dan $750 \mathrm{mg}$ dengan 7 sampel masing-masing sedangkan terendah pada kelompok $900 \mathrm{mg}$ dengan 2 sampel. Hal ini menunjukkan efek anti emetik gabapentin lebih baik dengan pemberian dosis yang lebih besar.

Penelitian yang dilakukan tahun 2017 dengan membandingkan efek gabapentin oral $900 \mathrm{mg}$ dengan $600 \mathrm{mg}$ pada pasien yang menjalani seksio sesarea dengan anestesi spinal didapatkan bahwa gabapentin oral $900 \mathrm{mg}$ lebih efektif daripada $600 \mathrm{mg}$ dalam mengurangi kejadian mual, dan muntah. ${ }^{4}$ Penelitian lainnya mengevaluasi efek gabapentin dan pregabalin pada manajemen nyeri pascabedah dan efeknya pada PONV dan efek samping seperti pusing dan sedasi, mereka menyimpulkan bahwa itu tidak mengurangi PONV jika dibandingkan dengan plasebo tetapi kombinasi gabapentin dan deksametason tampaknya memiliki efek sinergik pada pengurangan PONV dibandingkan dengan gabapentin atau deksametason saja. ${ }^{4}$ Gabapentin pra operasi dikaitkan dengan penurunan PONV pascabedah yang signifikan. Gabapentin praoperasi harus dipertimbangkan tidak hanya sebagai bagian dari pendekatan multimodal untuk analgesia pascabedah, tetapi juga untuk pencegahan PONV. ${ }^{15}$

\section{Simpulan}

Pemberian gabapentin oral $900 \mathrm{mg}$ memberikan durasi analgesia yang lebih panjang dan total rescue analgetik paling sedikit dibanding dengan pemberian gabapentin $600 \mathrm{mg}$ dan $750 \mathrm{mg}$. Ketiga kelompok gabapentin mengalami efek samping sedasi namun selama pengamatan didapatkan semua kelompok mengalami sedasi ringan yang tidak membutuhkan intervensi. Kejadian PONV paling rendah pada kelompok gabapentin 900 mg dimana hal ini menunjukan efek anti emetik gabapentin lebih baik dengan pemberian dosis lebih besar.

\section{Saran}

Dianjurkan untuk menggunakan gabapentin oral 
900 mg pada pasien pascabedah histerektomi karena memiliki durasi yang lebih lama dan penggunaan analgetik tambahan paling rendah dengan kejadian PONV yang lebih rendah. Setelah penelitian ini juga disarankan untuk dapat dilakukan penelitian lebih lanjut mengenai pemberian gabapentin oral pra-bedah dan pascabedah dosis berbeda pada jenis pembedahan lain.

\section{Daftar Pustaka}

1. Yacob MC, Ihsan MH, Wijaya DW. Perbandingan efektivitas antara gabapentin $600 \mathrm{mg}$ dan gabapentin $900 \mathrm{mg}$ kombinasi dengan ketorolak $30 \mathrm{mg} / 8$ jam sebagai analgesia pascabedah pada total abdominal histerektomi dengan anestesi umum. J Anest Periop. 2016; 4(3): 147-53.

2. Arumugam S, Lau CSM, Chamberlain RS. Use of preoperative gabapentin significantly reduce postoperative opiod consumption: a meta-analysis. J Pain Res. 2016;9: 631-40.

3. Agustine R, Oktaliansyah E, Surahman E. Perbandingan gabapentin $600 \mathrm{mg}$ dengan pregabalin $150 \mathrm{mg}$ preoperatif terhadap nilai numeric rating scale dan pengurangan kebutuhan opioid pascaoperasi modifikasi radikal mastektomi. J Anest Periop. 2014; 2(2): 117-23.

4. Hafez MH, Abdelhamid MH, Youssef MMI, Abdelrahim. Randomized controlled trial of two oral regimens of gabapentin versus placebo in patients for cesarean section under spinal anesthesia regarding postoperative pain, sedation, nausea and vomiting. Egyp J Anaes. 2017; 33: 59-65.

5. Khabi PM, Yaghooti AA, Marashi SH. Effect of pre-emptive gabapentin on postoperative pain following lower extremity orthopedic surgery under spinal anaesthesia. Sing Med J. 2011;52(12): 879-82.

6. Katz J, Clarke H. Preventive analgesia and beyond: current status, evidence and future direction. In: Macintyre P, editor. Clinical pain management acute pain. London: Hodder Arnold Ltd.2008. 154-98.

7. Zulfariansyah A, Nawawi AM, Bisri $T$. Perbandingan gabapentin $600 \mathrm{mg}$ dengan $1.200 \mathrm{mg}$ per oral preoperatif terhadap nilai visual analogue scale dan pengurangan kebutuhan petidin pascaoperasi pada modifikasi mastektomi radikal. J Anes Perio. 2013;1(3): 174-82.

8. Kandappan G, Raju TS. To evaluate the role of gabapentinasapreemptiveanalgesicinpatients undergoing total abdominal hysterectomy under spinal anaesthesia. Kour Evid Based Med Healthc. 2016; 3(49): 2487-91.

9. Butterworth JF, Mackey DC, Wasnick JD. Spinal, epidural \& caudal blocks. In:Morgan \& mikhail's clinical anesthesiology, 5th Ed. New York: McGraw Hill Education; 2013.937-58.

10. Bryson GL, MacNeil R, Jeyaraj LM, Rosaeg OP. Small dose spinal bupivacaine for cesarean delivery does not reduce hypotension but accelerates motor recovery. Can J Anesth. 2007;57(7):531-7.

11. Kjaer K, Kim J. Spinal and epidural blockade for gynecology surgery. In : Wong CA, editor. Spinal and epidural anesthesia. New York: McGraw-Hill; 2007. 247-56.

12. Yilmaz M, Wong CA. Technique of neuraxial anesthesia. In : Wong CA, editor. Spinal and epidural anesthesia. New York: McGrawHill; 2007. 33-44.

13. Braga AFA, Frias JAF, Braga FSS, Pereira RIC, Titotto SMMC. Spinal anesthesia for elective ceasarean section. Use of different doses of hyperbaric bupivacaine associated with morphine and clonidine. Act Cir Bras. 2013;28(1):23-32.

14. Schmidt PC, Ruchelli G, Mackey SC, Carrol IR. Perioperative gabapentinoids. choice of agent, dose, timing, and effects 
on chronic postsurgical pain. The American Society of Anesthesiologists, Inc. Lippincott Williams \& Wilkins. Anaesthesiology. 2013; 119:1215-21.

15. Grant MC, Lee HW, Page AJ, Hobson D, Wick $\mathrm{E}$, and $\mathrm{Wu} \mathrm{CL}$. The effect of preoperative gabapentin on postoperative nausea and vomiting: a meta- analysis. Anaesth Analg. 2016;122(4):976-85.
16. Achutan S, Singh I, Varthya SB, Srinivasan A, Chakrabarti A, Dota D. Gabapentin prophylaxis for postoperative nausea and vomiting in abdominal surgeries: a quantitative analysis of evidence from randomized controlled clinical trials. Brith J Anaesth. 2015;114(4): 588-97. 